Estudios sobre armas antiguas, armamento, arte militar y vida cultural en oriente y occidente

XXVI (2006), pp. 5-18

ISSN: 0435-029X

\title{
THE TACTICAL DEVELOPMENT OF ACHAEMENID CAVALRY
}

\author{
POR
}

\author{
ALEXANDER K. NEFEDKIN*
}

\begin{abstract}
RESUMEN
In the $6^{\text {th }}$ and first half of the $5^{\text {th }}$ century BC, Persian horsemen were armed with bows and javelins, and fought as a light cavalry. In the second half of the $5^{\text {th }}$ century in the western regions of the Persian empire there was an increase in heavily-armoured cavalry, armed with the spears (palta) for thrusting and throwing. I propose that this evolution is connected with the long wars against the Greeks and the deterioration of the morale quality of Persian warriors. The attempt of the last Persian king Darius III to re-arm his horsemen with lances to fight the Macedonian Companions did not succeed in saving the Achaemenid empire from collapse.
\end{abstract}

En el siglo VI y la primera mitad del siglo V A. C. los caballeros persianos fueron armados con arcos y jabalinas y luchaban como caballeria ligera. En la segunda mitad del siglo V A.C. en las regiones occidentales del Imperio Persa se extienden caballeros de armadura pesada, armados con lanzas (palta), aunque la mayor parte de caballeria estaba formada con armados ligeramente. Segun mi opinion, estos cambios en caballeria persiana eston relacionados con la lenta guerra contra los griegos y tambien con empeoramiento de completacion de caballeria local. El intento de Dario III de rearmar a sus caballeros con las lanzas largas para luchar con exito con caballeria macedonica, fracaso por causa de caida del Imperio Aquemenido.

\section{KeYwords - Palabras ClaVE}

Achaemenid Persian Cavalry. Tactics. Wesapons.

Caballería persa arqueménida. Tácticas. Armas.

It is well known that natural conditions exert an influence upon the evolution of social structure. The latter dictates military recruitment which in turn affects tactics. Tactical development therefore depends on a range of social factors, the enemies against whom the army routinely wages war, and, of course, the development of armaments ${ }^{1}$. In the ancient world progress in equestrianism especially depended on the natural conditions necessary for horsebreeding (cf. Plat. Leg. 1.625d). Consequently some tactical methods for cavalry that appeared on the battlefield were reflective of local circumstances. The Canadian colonel George T. Denison Jr. (1872: 61) rightly noted that cavalry tactics have always changed in response to the evolution of the troop types against which cavalry fought, as well as the tac-

* Department of the History of Greece and Rome of the Historical Faculty of St. Petersburg State University, Mendeleevskaja linija, 5, 199034 St. Petersburg, Russia, e-mail: nefiodkin@mail.ru. The work is supported by Alexander von Humboldt-Stiftung.

1 See, for example, the classic German book on the subject Jäns, 1885. 
tics and weaponry of the enemy. In the Ancient Near East the earliest cavalry tactics were those of light cavalry fighting with missiles. Once rulers began to organise their cavalry as an effective armed force, with training and quite often heavier equipment, cavalry could fight at close quarters not only against other horsemen, but also against infantry in array. During the 6th-4th centuries BC cavalry evolved in the Achaemenid empire. The primary sources for this subject are literary, while archaeological finds and pictorial evidence, as a rule, remain secondary.

By the end of the $7^{\text {th }} /$ first half of the 6th century BC, Persian and Median cavalry had apparently developed along similar lines. Their evolution was no doubt influenced by the Scythians who had been ruling in the Near East in the third quarter of the 7th century BC. Herodotus notes that the Scythians trained the Medes in archery (Hdt. 1.73). The passage claims that the noble Medes, the king's sons, fought on horseback as Scythians, while the Median tribesmen, armed mainly with missile weapons, were footmen (Xen. Cyr. 1.5.5; Strab. 15.3.18-19). Xenophon informs us about the tactics of early Achaemenid Median and Persian horsemen. He reports the way in which the mounted Medes were fighting in the 6th century BC (Xen. Cyr. 1.4.23; cf. 2.1.7-8.): «Now the enemy [the Assyrians] ${ }^{2}$ on their part, when they saw the Medes advance, halted, some with spears $\left(\pi \alpha \lambda \tau \alpha^{\prime}\right)$ poised, others with bows drawn, expecting that the other side would also halt as soon as they came within bowshot, just as they were accustomed generally to do; for it was their habit to advance only so far against each other, when they came into closest quarters, and to skirmish with missiles, oftentimes till evening» (translated by W. Miller). These were the usual tactics for light cavalry who could fight each other for a long period. The enemies approached each other up to a couple of hundred metres and deployed from a deep marching column into line in order to facilitate firing their missiles. Then they started shooting at each other ${ }^{3}$. At the same time groups of horsemen often raced out from their formation to attack the enemy, and then withdrew to their positions, while the enemy's cavalrymen pursued them. During the war against Lydia (547 BC) the Persian cavalry was still weak. They were unable to withstand the charge of the Lydian mounted lancers and for this reason the Persian king Cyrus II deployed packcamels against them whose appearance and smell frightened the enemy's horses (Hdt. 1.80; Xen. Cyr. 6.2.18; 7.1.22, 27; Front. Strat. 2.4.12; Polyaen. 7.6.6; Ael. Nat. anim. 3.7, 11.36; cf. Procop. Bel. Vand. 2.11.48)

In $530 \mathrm{BC}$ the army of Cyrus the Great fought against the Massagetae nomads in the same way using missile weapons. Herodotus (1.214) says «This battle was the fiercest that has ever been fought between barbarian peoples... It is said that at first they stood apart and shot arrows at each other and that then, when their arrows were used up, they fell to hand-tohand combat with spears and daggers. They stood fighting together for a long time, with neither side wanting to... run, but in the end the Massagetae prevailed. Most of the Persian army was killed right there in battle, and yes, even Cyrus died...» (translated by W. Blanco). The troops of the Persians and Massagetae included both cavalry and infantry and the tactics of the two armies were the same: a prolonged archery exchange, after which the warriors passed to hand-to-hand fighting with spears and short swords (akinakes) once their stock of arrows was spent. These were typical tactics for mounted and foot archers. For example, the Mongols, for the most part horse-archers, fought in this way in the 13th century (Marco Polo, chap. 198, 201, 208, 225; cf. 79, 122-123).

2 The Babylonians of the Neo-Babylonian empire are styled Assyrians by Xenophon and other authors (Xen. Cyr. 1.4.16, 5.2-3; 2.1.5; 5.2.26, 3.5; 6.1.25; cf. Hdt. 1.106, 178, 188, 192-193, 199; 2.50; 3.55; Strab. 16.1.16, 20).

3 On the basis of ancient data W. McLeod (1965: 8) defines the rang of an ancient composite bow from 6070 to $160-175 \mathrm{~m}$, but not more than $350-450 \mathrm{~m}$.

4 The Professor of German of St. Petersburg State University Galina Fedorova remembered that when she was in the camp near Astrakhan (1942), the wagon's horses were frightened by the camels even at a distance. 


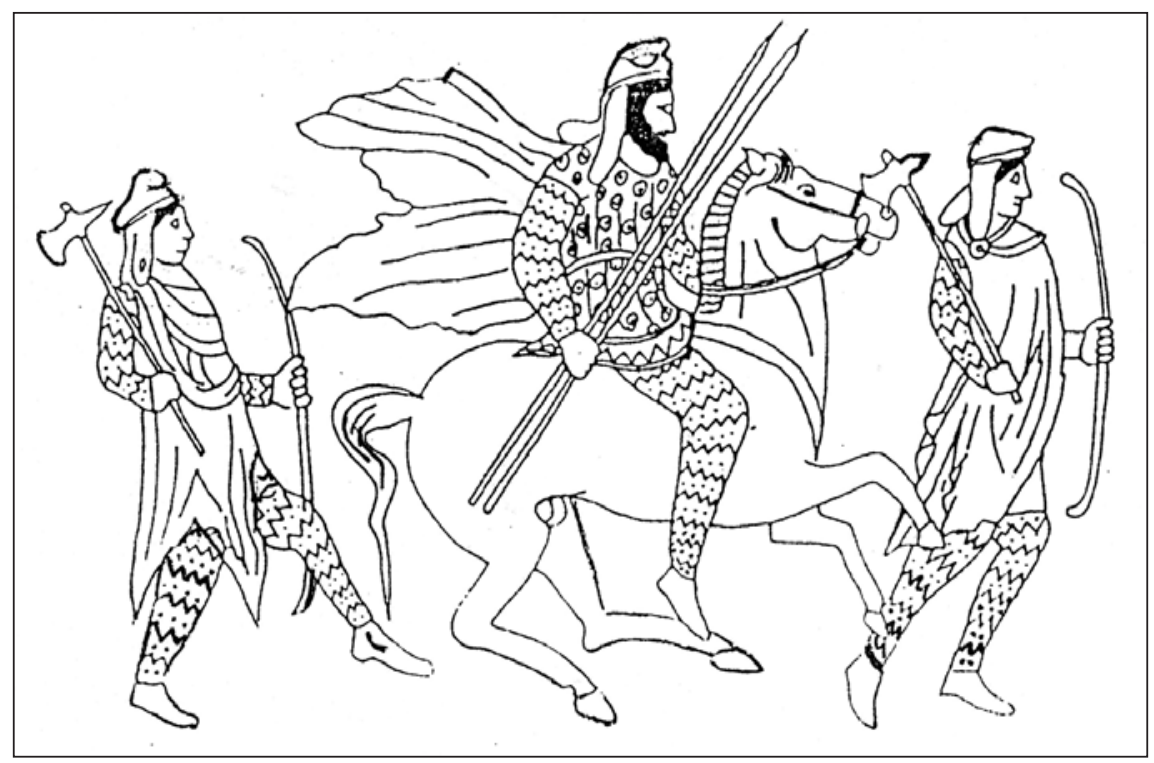

Fig. 1. The Persians. The drawing of the read-figure crater from Naples (the 4th century BC). Note the chlamydes are untypical for the Persians. The horse without the saddle blanket is a Greek feature. After Bittner, 1985: Taf. 7.1.

Having occupied the Near and Middle East, the Achaemenids began to develop their cavalry. They distributed fiefs to the Persians, Medes, Hyrcanians and other peoples, and landholders were obliged to send armed horsemen to the king's army (Xen. Cyr. 8.4.28, 6.10-11, 8.20). Neo-Babylonian tablets refer to «land of bow», «horse», or «chariot». «Land of horse» (bit sì sî) is known from a tablet from Sippar, dated to $523 \mathrm{BC}$, in which a fief is called bit aspatu (VS. V.55). This document informs us that one Babylonian Ili-aqabi leased a piece of such land. G. Cardascia (1951: 8, n. 7) specifies that the bit aspatu is an Iranian parallel to the Akkadian bìt sis $\hat{s}$, formed from the Persian root asp- («horse»). M. A. Dandamayev explains that the Iranian word replaced the Akkadian one when this system of land tenure was introduced by the Persians (Dandamayev, Lukonin 1980: 159). But it is difficult to understand the relationship between the bìt si sî and bìt ritti («land of hand») because in the tablet the former is a subset of the latter. The bit ritti was a state-owned estate worked by a temple or other officers paying taxes to the king; it was not land connected with military service (Joannès 1981: 9-16, 43-44; Stolper 1985: 25, n. 97). It was perhaps with good reason that Xenophon attributed the creation of the Persian cavalry to Cyrus the Great (Cyr. 4.3.4-26, 5.58).

By the time of Darius I's Scythian campaign (between 514 and 511 BC) the Achaemenid cavalry were still forced to yield to Scythian horsemen, nomads who practised equestrianism from childhood. The Persian cavalry had to retreat in the face of the Scythian horse-archers' attack and seek the protection of its infantry, which the nomads did not dare attack. Herodotus (4.128) describes these tactics thus: «The Scythian horse always routed the Persian horse, and when the Persian cavalry would fall back in flight on their infantry, the infantry would come up to their aid; and the Scythians, once they had driven in the horse, turned back for fear of the infantry» (translated by A.D. Godley). It is clear that the Persian cavalry continued to fight using the same methods as previously, though Xenophon attributes to Cyrus II the arming of horsemen with a heavy palton instead of missile weapons (Cyr. 4.3.9, 58). The palton was a specific Persian spear which could be use as a javelin and a lance (Xen. Cyr. 4.3.9; De re eq. 12,12 ; see figs. $1,6,9,10,12$ ). It is most likely, however, that Xenophon is writing about the 


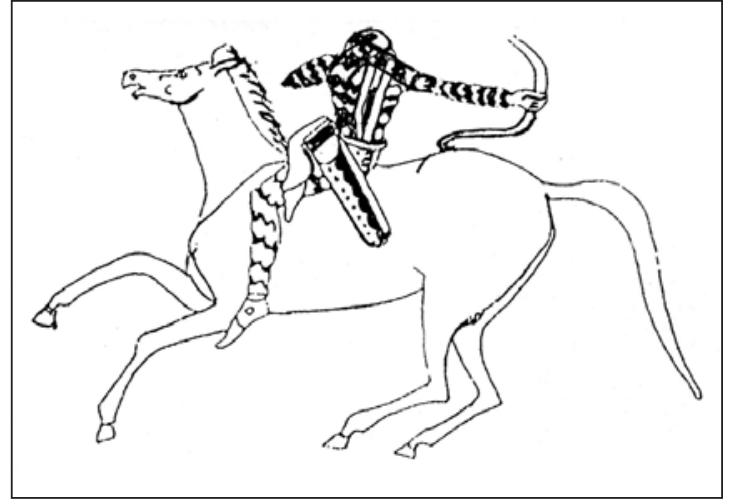

Fig. 2. Persian mounted bowman. The drawing of the cup of the master Triptolemus (probable the 470s BC). After Head, 1992: Fig. $12 \mathrm{~b}$.

cavalry of his own time, i.e. the late 5th/ early 4th century BC (Xen. Cyr. 4.3.23; 7.1.46; 8.8.22; Diakonoff 1956: 29-34; Breitenbach 1967: 1716; Frolov 1976: 257-258; 1991: 315-316). Xenophon drafted his description of Cyrus' military reforms to publicise his own ideas about the superiority of close-quarter weaponry over missile weapons (Cyr. 2.1.7, 9, 3.17-20; 4.2.24; cf. 1,2,13).

Had the tactics of the Achaemenid cavalry changed by the beginning of the Graeco-Persian wars in the very early 5th century BC? Herodotus (7.84) informs us about the arms and armament of the mounted Persians in Xerxes' army as follows: «The Persians, equipped like their infantry, except that some of them wore headgear of hammered bronze and iron» (translated by A.D. Godley). He describes the Persian foot in this way (7.61): «They wore on their heads loose caps called tiaras, and on their bodies embroidered sleeved tunics, with scales of iron like the scales of fish in appearance, and trousers on their legs; for shields they had wicker bucklers ( $\gamma \dot{\varepsilon} \rho \dot{\rho} \alpha)$, with quivers hanging beneath them; they carried short spears, long bows, and reed arrows, and daggers that hung from the girdle by the right thigh» (translated by A.D. Godley). Accordingly, the Persian cavalry were armed with bows and

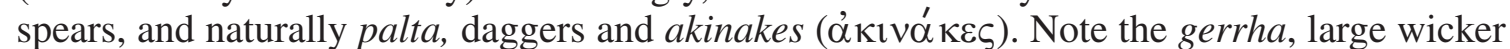
shields, were arms of infantrymen alone ${ }^{5}$. The horsemen wore iron scale corselets and bronze or iron helmets (Hdt. 7.84; cf. 7.61; 9.22; Plut. Aristid. 14,6) ${ }^{6}$. We can observe the tactics of these cavalry in combat against the Greeks. Herodotus describes the attack of the Persian horsemen at Plataea in the 479 BC in this way (Hdt. 9.49): «The horsemen rode at them [the Greeks] and shot

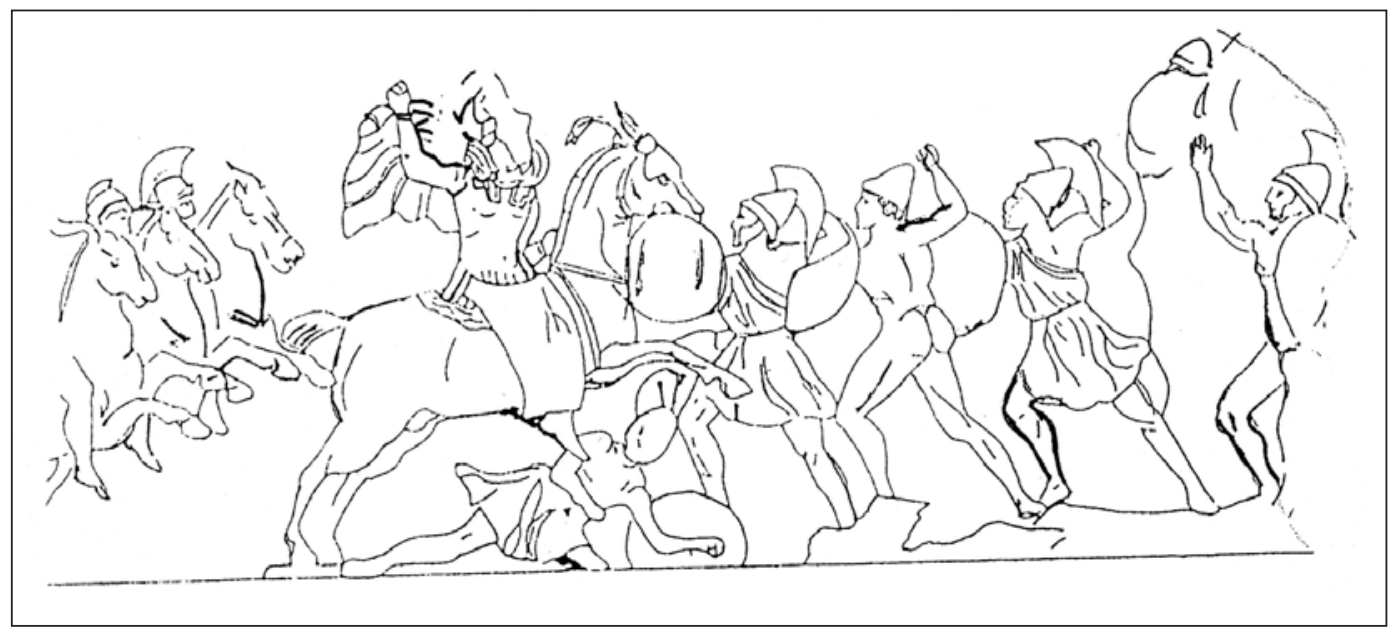

Fig. 3. The drawing of the left longitudinal wall of the relief of Payava's sarcophagus showing the charge of the Lycian cavalry on the Pisidian (?) footmen (375-362 BC). After Nikulina, 1994: Fig. 70.

\footnotetext{
5 Head, 1992: 37.

6 On the armour of the Achaemenid Persians and Medes see in detail: Gorelik 1982: 90-106.
} 
arrows and javelins among the whole Greek army to its great hurt, since they were mounted archers and difficult to deal with in an encounter» (translated by A.D. Godley; cf. Hdt. 9.18, 20, 22). On the basis of this passage it would appear that the main weapon of the Persian cavalry was the bow (Hignett 1963: 45; Khazanov 1968: 186). However, it is clear from Herodotus' information that the Persian horsemen were not only bowmen, but also javelineers (Hdt. 7.61, 84; cf. Xen. Cyr. 1.2.12, 4.4; 2.1.7; 6.2.16; figs. 2, 4, 5, 13). The prevalence of mounted archers, of course, is a result of the presence in the Mardonius' army of a large contingent of peoples from Central Asia, whose high quality the «Father of history» notes elsewhere (Hdt. 9.71). At this time the Persian battle-line comprised foot archers protected

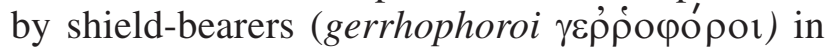
the front, while the horsemen were placed on the flanks. In the early 5 th century BC the tactics of the Achaemenid cavalry were those typical of light cav-

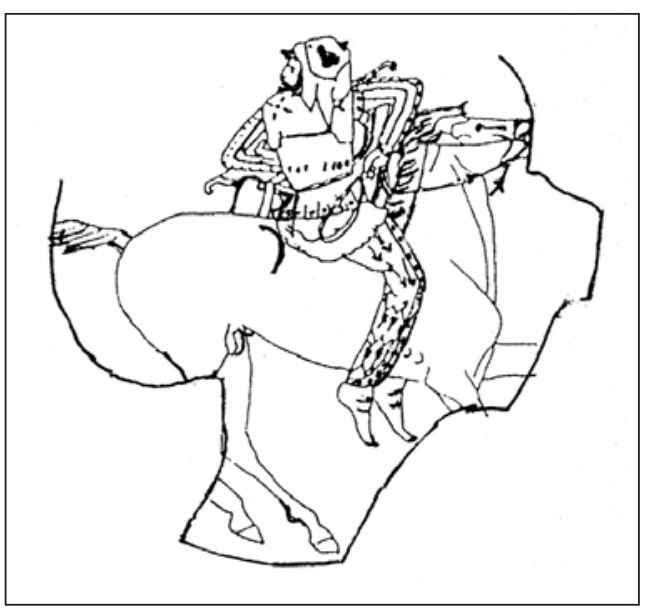

Fig. 4. The eastern horseman wearing the Greek corselet and chiton. The drawing of the read-figure kylix from Orvieto (the first half of the 5th century BC). After Stähler, 1992: Abb. 16. alry and traditional for the Persians: they discharged missiles at the enemy array and launched sudden attacks against their opponent's dispositions, especially its flanks (Evans 1984: 14). However, the charges of the Persian horsemen against the Greek hoplites' phalanx were not successful (Hdt. 9.23, 25; cf. figs. 5, 9, 12).

A charge of light cavalrymen against Greek hoplites is depicted on a Clazomenian sarcophagus (fig. 13) ${ }^{7}$. These horsemen are armed with yatagan-shaped swords (machaerae) and

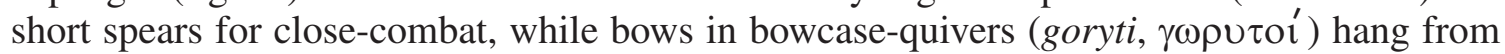
their belts. These features most probably indicate that these horsemen are of Persian origin, and not Eurasian nomads - Cimmerians or Scythians. The date of the sarcophagus (ca. 500 BC) also supports this conclusion. Dogs assist the horsemen in the battle, though classical sources do not mention the Persian employment of war-dogs. These animals were mostly used by the inhabitants of Western Anatolia (Plin. NH. 8.143; Poll. 5.47; Polyaen. 7.2.1; Ael. Var. Hist. 13.46) and by the Caspians and Hyrcanians (Val. Flac. Argon. 6.106-108; Ael. NA. 7.38), and the Persians might have adopted their use in the battle from these peoples (cf. Hdt. 7.187) ${ }^{8}$. However, it is more likely that the dogs depicted on Clazomenian sarcophagi had a sacred meaning, rather than a historical significance (Moleva 1998: 61-62). In these depictions Persian horsemen charge against the disordered ranks of Greek hoplites, who have already lost some warriors killed and wounded. In these circumstances the attack might achieve good results, as a cavalry charge has more psychological than physical force. An infantryman fears that a horse might knock him down and wound him with its hoofs, while the rider attacks him with his weapons (Marmont 1846: 53-54; Nolan 1854: 273; Keegan 1986: 95-97). We know that the retreat of the Persian troops at Plataea from the attacking Greeks was protected not only by Persian cavalry, still too weak to fight against hoplites, but primarily by Boeotian cavalry, who knew how to resist Hellenes (Hdt. 9.68-69). Herodotus (9.68) writes: «They accordingly all fled, save the cavalry, Boeotian and other; this helped the fleeing men in so far as it remained between them and their enemies and shielded its friends

7 Murray 1898: Pl. I; cf. Pottier 1892: 244, fig. 2 (a sarcophagus fragment showing the battle between Greek hoplites and Thracian and Oriental horsemen).

${ }^{8}$ See in detail Cougny 1877: 888-889; Orth 1913: 2566-2567; Cook 1952: 38-42. 


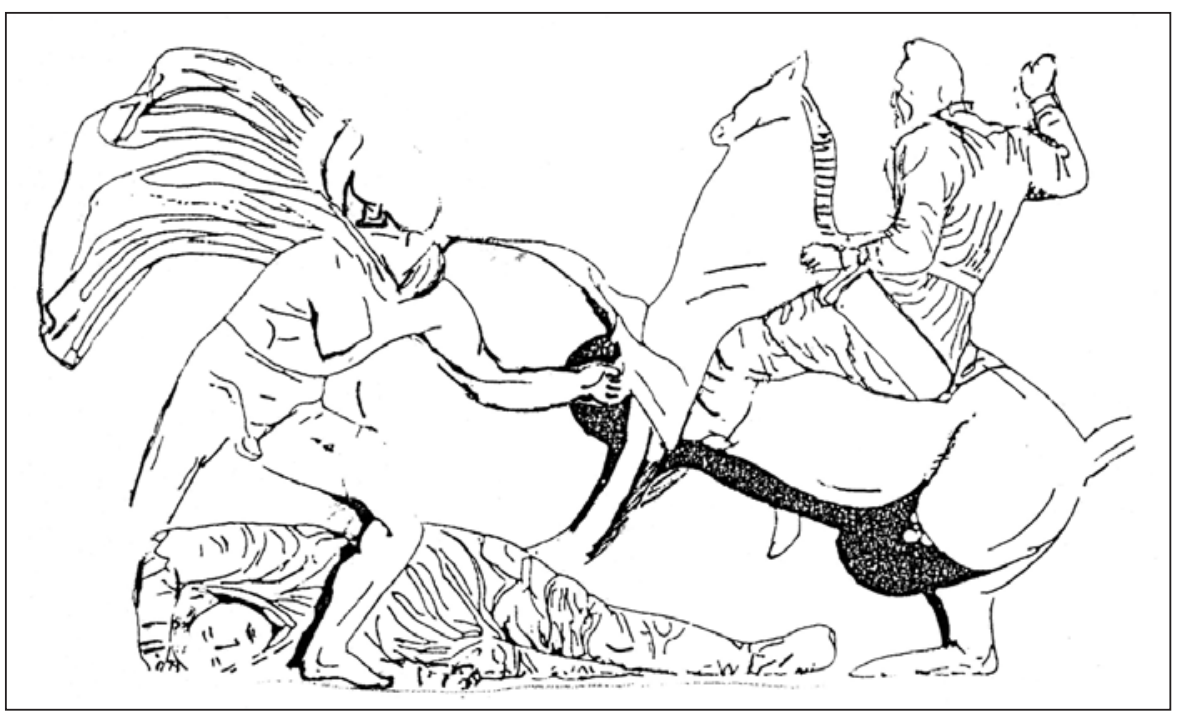

Fig. 5. The drawing of the relief representing the fight of the Greeks and Persians, the southern frieze of the Nica's temple at Athens (ca. 425 BC). Probably it is the battle of Plataea. After Stähler, 1992: Abb. 20g.

from the Greeks in their flight» (translated by A.D. Godley). Thus the Achaemenid cavalry, without supporting infantry, could not fight against Greek hoplites and the picture on the sarcophagus shows us the final stage of a battle when the hoplite line has already broken.

In the 460-450s BC some changes were introduced into the structure of Persian levies from the Western satrapies (Sekunda 1992: 18, 21-22, 24; Nefedkin 2001: 407). The number of infantrymen armed like peltasts was considerably increased and they frequently became the main force of an army. It is probable that they were drawn mainly from the inhabitants of Anatolia (fig. 3). At the same time, heavily-armoured horsemen also appeared, their horses protected with chamfrons, peytrals and thigh-pieces (figs. 3, 10). The offensive weaponry of these riders consisted of the sword and two palta, often without a bow (Xen. An. 1.5.15, 8.3, 6-7; Cyr. 6.4.1; 7.1.2; Diod. 14.22.6; cf. figs. 1, 6, 9, 10, 12). Some of the horsemen had only one palton (Xen. Cyr. 4.3.58; 6.2.16; 8.8.22). The latter was both a missile and hand-to-hand weapon. There is no firm evidence for Persian horsemen using shields in the mid-5th century, as Duncan Head (1992: 37-38) and Nicholas Sekunda (1992: 21) suggest. The horsemen on the relief from Yeniceköy, perhaps, do not have rectangular shields, but rather sleeved clothing, the

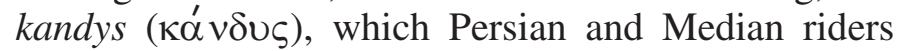
often wore draped across the shoulders as a cloak (Head 1992: 39; see Munro 1912: Pt. 1. P. 66, fig. 2; see fig. 10; cf. fig. 8). There is a clay tablet from Nippur that contains a contract between the Mirashu family business and one Gadal-iama in the 421 BC. He asks the firm for military equipment including a bronze shield and an iron «club», perhaps umbo (UCP. 9.275; see Ebeling 1952: 210; Rahe 1980: 91-92). The cavalryman might have wielded a shield when he dismount-

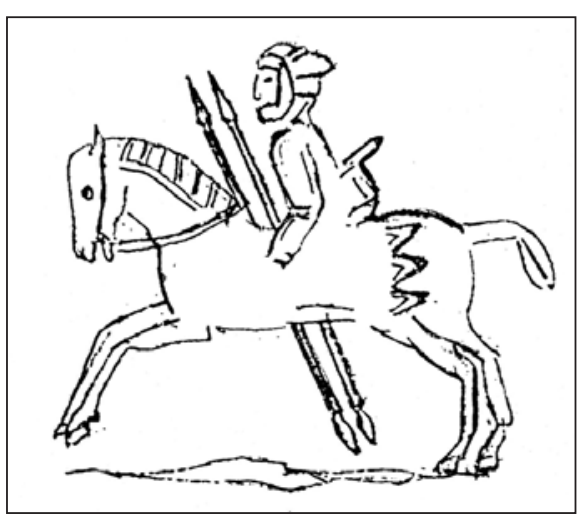

Fig. 6. The drawing of the Persian horseman on the chalcedony stamp-seal (probably the second half of the 4th century BC). After Sekunda, 1992: 25. 


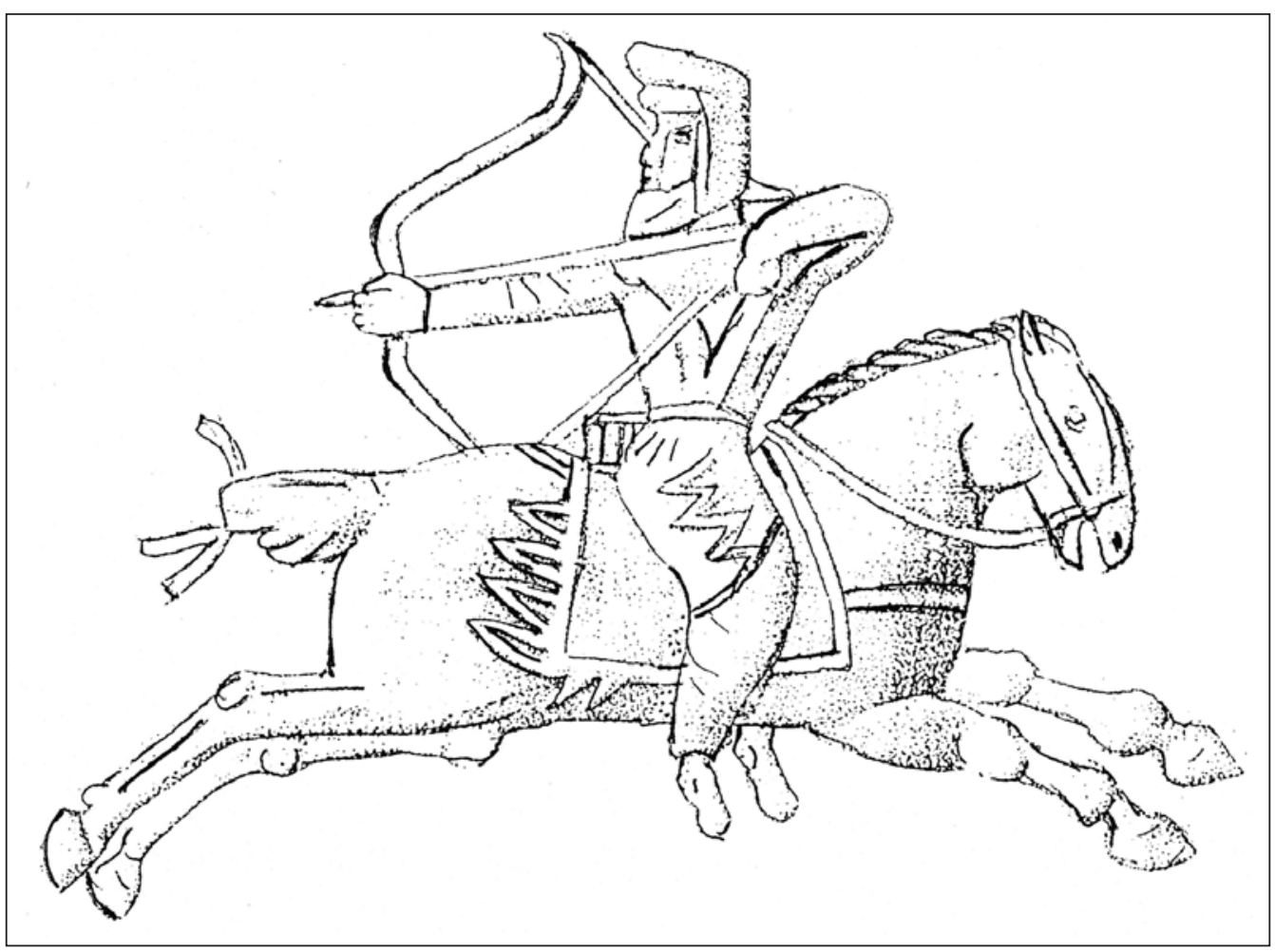

Fig. 7. The Persian, armed with the tiara, hunting a lion. The drawing of a fragment of the chalcedony cylindrical seal (the 4th century BC). After Littauer, 1979: Fig. 85.

ed, but to my knowledge there is no other evidence for Achaemenid cavalry using shields. Bronze shields were typical in the Near East in the earlier period (the 8th-7th centuries BC), but in Mesopotamia the panoply of a horseman did not include a shield.

Only noble Achaemenid cavalrymen possessed armour. They were usually the guards of a governor or members of a landowner's family (cf. Xen. Hel. 3.4.10; Plut. Ages. 8,3). Thus, in the mid-5th century BC, Persian horsemen were not mounted horse-archers, but heavier armoured cavalrymen equipped with palta. They were able to fight in close-combat for which more extensive bodily protection was especially necessary.

In this epoch cavalry did not need to be formed in a loose line for firing missiles. In the later 5th / early 4th century BC, Achaemenid cavalry used to form into deep columns for the charge and more easily overwhelmed Greek cavalry, but Persian horsemen did not usually charge the close phalanx of the Hellenic hoplites (Xen. Hell. 3.4.13-14, 23-24; Ages. 1.30-32; Hell. Oxyr. 6.1-2; Plut. Ages. 10; Paus. 3.9.6). «Square formations» ( $\tau \varepsilon \tau \rho \alpha ́ \gamma \omega v o 1 ~ \tau \alpha ́ \xi \varepsilon 1 \varsigma)$ came to be considered by Greek tacticians as the usual deployment for Persian cavalry (Polyb. 12.18.2-5; Asclep. Tact. 7.3; Ael. Tact. 18.5; Arr. Tact. 16.9). Contemporary cavalry tactics are described by Xenophon (Hell. 3.4.13-14) in his account of the engagement at Dascyleium in the 396 BC: «Most of the time he [Agesilaus] pursued his march through the country in safety; but when he was not far from Dascyleium, his horsemen, who were going on ahead of him, rode to the top of a hill so as to see what was in front. And by chance the horsemen of Pharnabazus, under the command of Rhathines and Bagaeus, his bastard brother, just about equal to the Greek cavalry in number, had been sent out by Pharnabazus and likewise rode to the top of this same hill. And when the two squadrons saw one another, not so much as four plethra apart 


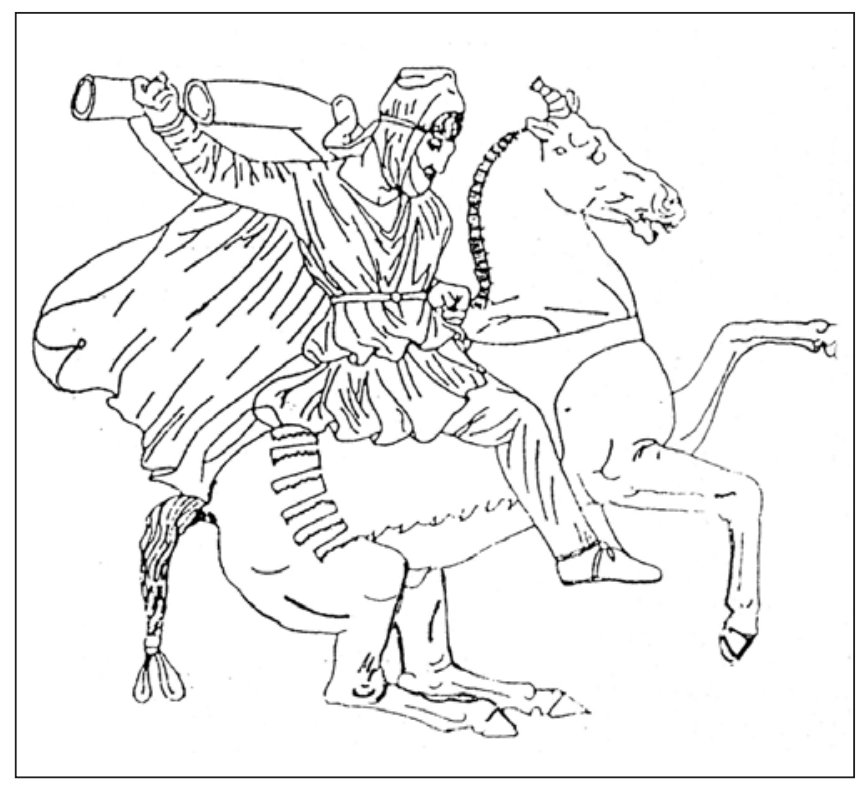

Fig. 8. The noble Persian horseman. The drawing of the bas-relief of the western longitudinal wall of the «Alexander Sarcophagus» at Sidon (the later 4th century BC). From Bittner, 1985: Taf. 41.1. [around $120 \mathrm{~m}$ ], at first both halted, the Greek horsemen being drawn up four deep like a phalanx, and the barbarians with a front of not more than twelve, but many men deep. Then, however, the barbarians charged. When they came to a hand-to-hand encounter, all of the Greeks who struck anyone broke their spears, while the barbarians, being armed with palta of cornelwood, speedily killed twelve men and two horses. Thereupon the Greeks were turned to flight. But when Agesilaus came to the rescue with the hoplites, the barbarians withdrew again and one of them was killed» (translated by C.L. Brownson). In this instance the Persian formation was not a marching column, but, like the Greek deployment, a battle-formation. Both the Greek and Persian cavalry's vanguards were therefore advancing in battle-formation since an encounter

with the enemy was very likely and because the terrain permitted this deployment.

How are we to explain the transformation of the Persian battle-order and, correspondingly, Persian tactics in the late 5th - early 4th centuries BC? A deep formation was usually reflective of the low quality of the warriors, and this is especially the case with cavalry: troopers of lower quality were placed in the middle ranks of a battle-array (cf. Arr. Tact. 35.5-6; Mauric. Strat. 2.6; Leo. Tact. 12.40-45; see Agapeev 1902: 241-242). The deep formation of the Persian horsemen is evidently explained the following way: the most noble and well-armed and armoured riders were in front, while the guardsmen and armed retainers were crowded behind them. The noblemen had to fight at the front of the array to justify their social status. In the course of the charge a «wedge» could evolve out of the deep mounted formation, when the commander and the bravest horsemen rode ahead and other riders, the large part of the charging cavalry, followed them forming a triangle-shaped formation (Arr. An. 1.15.7; Delbrïck 1921: 32-34; cf. figs. 3, 10). The deterioration in the morale of the Persian landholders' cavalry was related to changes in recruitment: landholders preferred to employ mounted retainers and servants for military service rather than take the field themselves. It is not only Xenophon (Cyr. 8.8.19-22) who informs us about this development, but also the

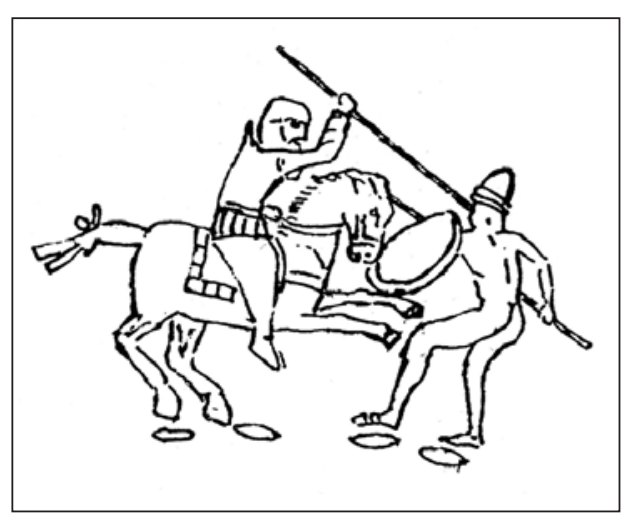

Fig. 9. The drawing of the single-combat of the Persian horseman and Greek hoplites. The Graeco-Persian seal (the 4th century BC). After Stähler, 1992: Taf. 6.3. above-mentioned Nippurian cuneiform tablet in which Gadal-iama is hired for service in a landholder's cavalry. These mercenary fighters did not aspire to be in the first ranks and place themselves in danger, but preferred to be within the depth of the formation. The commanders had to put the bravest riders in front of the mounted ar- 


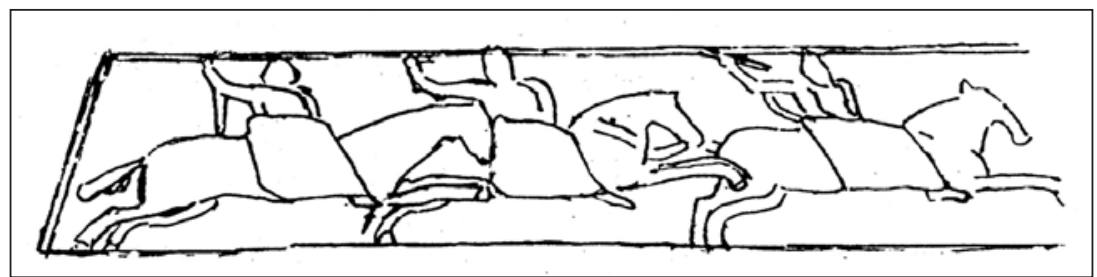

Fig. 10. The horsemen protected with thigh-pieces and armed with palta. The drawing of the Yeniceköy relief, Hellespontic Phrygia (the late 5th / the early 4th century BC). The bottom view. After Munro, 1912: Pt. 1. P. 66, fig. 2.

ray in order to overwhelm the enemy's cavalry using the depth of the formation (cf. Arr. Tact. 35.5-6; Leo. Tact. 12.40-45) ${ }^{9}$. In a close formation even the poorest warriors felt supported by their companions and bravely went into the fight. In these circumstances it is not a question of physical impetus, but rather the psychological impact upon the fighters (Golovin 1907: 136137, 156-157).

The predominance of the palton over the bow in cavalry equipment was possibly connected with the characteristic deterioration of the Persian cavalry, because it is difficult to shoot from a deep formation, and besides an adequate level of archery requires much more time to learn than throwing a javelin ${ }^{10}$. It was probably in the second half of the 4th century $\mathrm{BC}$ that a new type of javelin became widespread among Persian cavalry, the meságkulon, which had a loop affixed to its middle to facilitate throwing. A scholion to the Andromache of Euripides describes this weapon (1133): «mesankylona are a type of javelin, tied around the middle by cord, by holding which [the javelin] is thrown» (see Winter 1912: Taf. 13-14; Andreae 1977: Abb. 25). The spread of this new kind of javelin probably indicates the increased importance of missiles and, consequently, a further deterioration in the fighting quality of the main body of the Achaemenid cavalry.

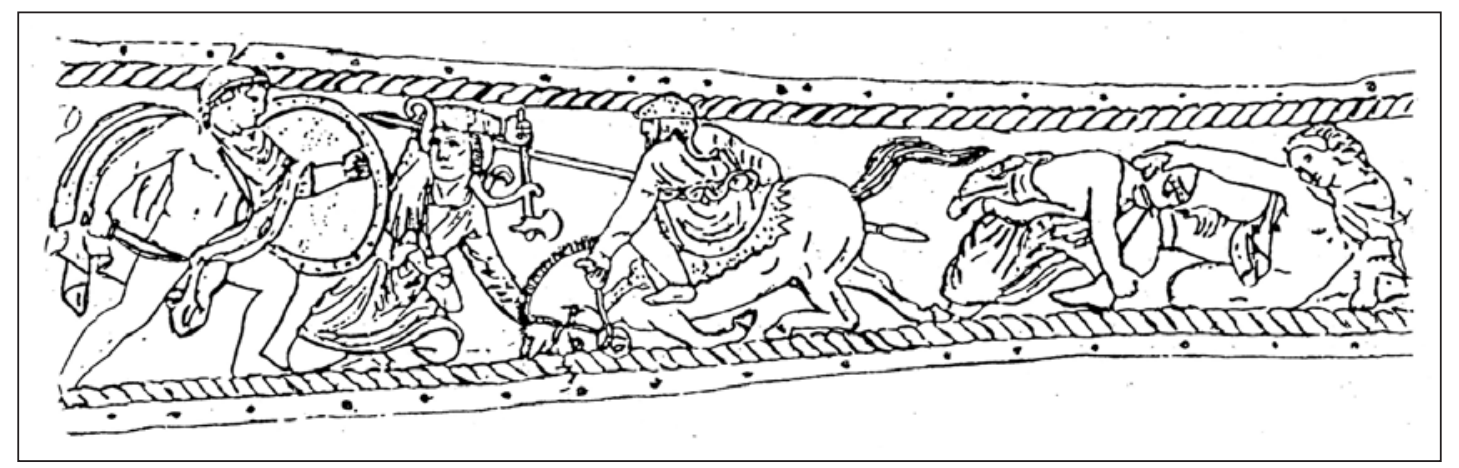

Fig. 11. The Persian cavalryman armed with the long lance. The drawing of the gold akinakes sheaths from Scytian king's tumulus Chertomlyk (the 320s BC). From Tolstoj, Kondakov, 1889: Fig. 3.

9 Compare the remarks of the cavalry general-major Charle-Emmanuel de Warnery on the close-formation of a squadron: «Un escadron doit être forme sur trois rangs ... et sur deux seulement il n'auroit pas assés de force ni de poids \& ne pourroit fournir le choc, au lieu que sur trois les deux derniers non seulement poussent le premier, mais même ils l'empéchent de s'arrètes \& reculer: les chevaux eux mêmes s'empressent d'avancer, lors qu'ils sentent derriere eux ceux qui serrent la coupe \& qui leur donnent des atteintes avec les pieds de devant» (Warnery 1781: 55-56).

10 In the Gadal-iama's tablet two spears and 130 arrows are specified in his armament, but there is no mention of a bow; he probably already possessed this item (UCP. 9. 275). 


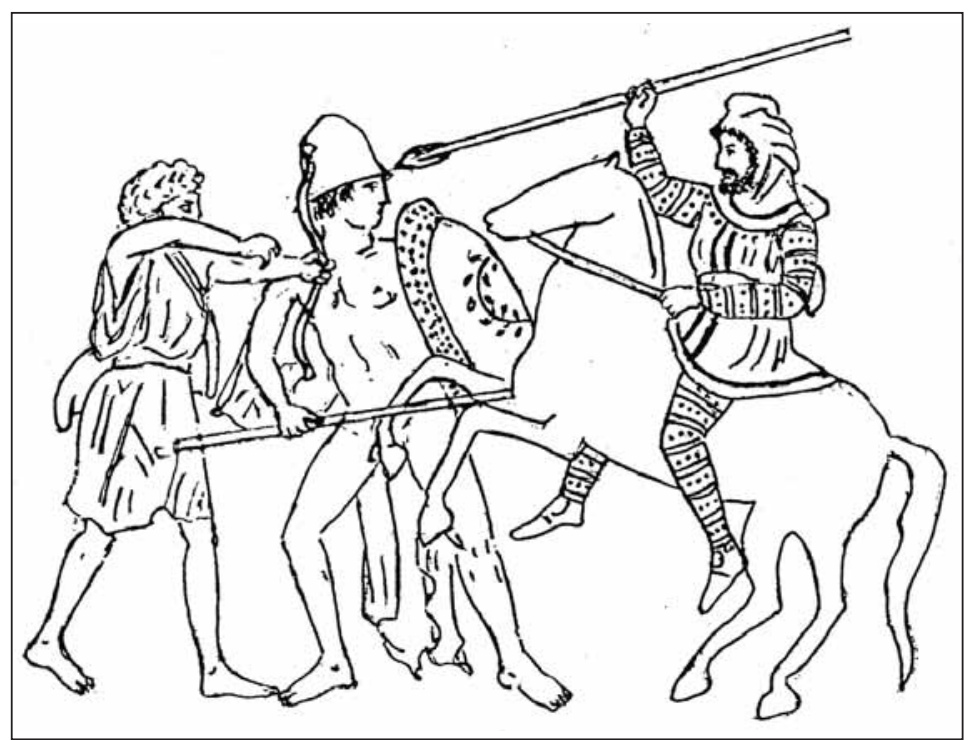

Fig. 12. The drawing of the Persian horseman, Greek archer and hoplites. The Attic red-figure hydria (the early 4th century BC). After Anderson, 1970: Pl. 19.
Clearly all the changes in the Persian military, which begun in the mid-5th century BC, were connected with the long war against the Greeks. Scythed chariots appeared at the same time, which allowed the Persians to break the Hellenic phalanx. The charge of their armoured cavalry would subsequently penetrate breaches made in the enemy's formation, while the «peltasts» (usually Anatolians) played an auxiliary role in the fighting (cf. Xen. Cyr. 7.1.9, 28; Hell. 4.1.17$19)^{11}$. The commander was frequently in the front line of the charging cavalry. The role of the cavalry charge was to break through the enemy's guards, kill their commander and, in consequence, decide the fate of a battle (Xen. An. 1.8.24-26). In the Asiatic style of fighting the heavily-armoured horsemen were an arrow-point directed against the enemy's general. These tactics were probably based on the traditions of the Heroic Age, when a duel between opposing generals escorted by their bodyguards was the main phase of combat.

In the Achaemenid army the tendency to increase the number of the armoured mounted spear-men was intensified by the encounter with the Macedonian Companions at the battle of the River Granicus (334 BC). The Companions, armed with long lances, were armoured cavalrymen who had neither greaves nor shields. They fought in deep and close squadrons. Arrian (An. 1.15.5) accounts for the defeat of the Persian cavalry in hand-to-hand fighting at the Granicus by the fact that the Macedonian cavalry was armed with cornel-wood lances $(\xi \cup \sigma-$

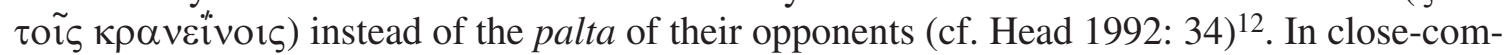
bat the lance appeared to be a more convenient weapon and was highly effective in the experienced hands of a cavalryman (Anisimov 1912: 4-5). The higher standards of training among the Macedonian Companions, together with their tactic of thrusting their spear into the opponent's face, unexpected by the Persian riders, resulted in their success in combat. The Persians relied on throwing their palta at the beginning of the action, after which they could fight in at close quarters with a palton held in reserved or with swords (Arr. An. 1.15.2-5), whereas the Macedonian Companions passed immediately to close-quarters combat. On the other hand, Xenophon considers a pair of palta as better weaponry for a cavalryman than one spear (De re eq. 12.12). The author based this conclusion on his own military experience: in his day in combat between Greek cavalrymen armed with lances and Persian horsemen equipped with two palta the former were defeated, as at the battle of Dascyleium in 396 BC (Xen. Hell. 3.4.13) ${ }^{13}$.

After the battle of the River Granicus Darius III started to increase the number of horsemen equipped with lamellar armour capable of resisting Alexander's cavalry in close combat.

11 In detail see Nefedkin 1997: 22-26 (summary in English); 2001: 406-409 (in Russian); Nefiodkin 2004 (in English).

12 On the battle of the Granicus see Hammond 1980: 80-88, especially p. 85.

13 Note a Greek horseman's lance was about $2,7 \mathrm{~m}$ long in the early 4th century BC. See the Panaitios relief (Sekunda 1994: 186. N. ${ }^{\circ}$ 207). 


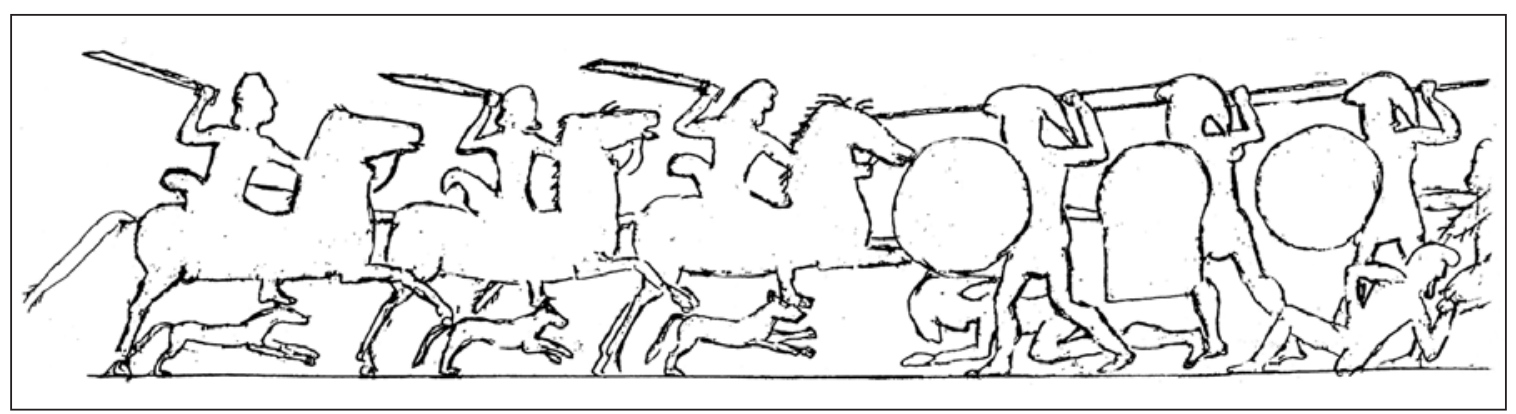

Fig. 13. The fight of the Persian horsemen and the Greek hoplites. The drawing of Clazomenian terracotta sarcophagus (ca. 500 BC). After Greenhalgh, 1973: Fig. 77.

At the battle of Issus (333 BC) the Persians already had heavily-armoured horsemen who fought -not unsuccessfully- against the Thessalian cavalry at close quarters (Curt. 3.11.15; Arr. An. 2.11.3). Having been defeated in this battle, the Persian ruler continued to prepare for war, training and arming his levies. Diodorus (17.53.1) tells us that Darius III armed his army with swords and longer lances ( $\tau \dot{\alpha} . . . \xi^{\prime} \varphi \eta \kappa \alpha \dot{\imath} \tau \dot{\alpha} \xi \nu \sigma \tau \dot{\alpha}$ ) before the battle of Gaugamela in the $331 \mathrm{BC}$. Curtius informs us that Persian warriors previously armed with javelins (jaculae) were now also equipped with swords and shields (4.9.3: scuta, gladii). This information relates to re-armament of the Achaemenid foot, but equipping the Persian horsemen with lances was a logical measure, as it increased their chances of victory in hand-tohand fighting against the Companions ${ }^{14}$. A reflection of this reform can be found in the picture of a Persian horseman with a long lance (about 3,5 m) on the gold akinakes sheaths from the Scythian king's tumulus at Chertomlyk, from the 8th barrow in the «Five brothers» group, and on the sheath which came from the tumulus at Chayan in the north-western Crimea and now in the Metropolitan Museum (fig. 11) ${ }^{15}$. The traditional date of the sheaths is the second half of the 4th century BC, and that from Chertomlyk 350/340-320 BC. I believe that the akinakes sheaths could date to $331-320 \mathrm{BC}^{16}$.

At the battle of Gaugamela the mounted Massagetae on Darius III's left wing and the Persian, Parthian and Indian horsemen on his right employed close-combat tactics (Arr. An. 3.13.4; cf. Curt. 4.9.3). Arrian (An. 3.15.2) reports: «There was no javelin-throwing and no manoeuvring of horses, such as are usual in a cavalry engagement, but each tried to break his way through whatever opposed him» (translated by P. A. Brunt). In fact, this passage describes Darius' horsemen attempting to break through an encircling enemy, an action forced upon them, and consequently Arrian notes the rarity of this style of fighting. In 331 $\mathrm{BC}$ and later the main body of the Persian cavalry were composed of javelineers armed with mesankyla (Arr. An. 7.6.5; cf. figs. 6, 8, 9). They formed in deep formation for combat (Arr. An. 3.15.2), and fought with missiles and at close-quarters. Later, in 317 BC, Antigonus the One-Eyed had Median horsemen armed with light spears $(\lambda o ́ \gamma \chi \alpha \imath)$ and Parthian horsearchers (Diod. 19.29.2). The Medes, as I mentioned above, since Herodotus' time, did not differ from the Persians in their equipment nor, in consequence, in tactics. So, the re-armament of the Persian cavalry with lances had no long-term consequences after the fall of the Achaemenid empire.

14 On the reform see Bittner 1985: 293-294; Sekunda 1992: 29; Nikonorov 1997: 22.

15 I am indebted to V. P. Nikonorov for drawing my attention to the lance. See Alexeev, Murzin, Rolle 1994: 105, \# 191; Shilov 1961: 158-166. Figs. 11-12; Richter 1931: 44-48. Figs. 1-3; Mertens 1987: 79, fig. 59.

16 In the detail see Nefedkin 1998: 71-76. On the tradition date of Chertomlyk see Alexeev 2001: 137-140 (329/8 BC). 
In conclusion, in the 6th and first half of the 5th centuries BC Persian cavalry were armed with bows and javelins. They fought as light irregular cavalry using hit-and-run tactics ${ }^{17}$. The second half of the 5th century BC saw changes in the military forces of the western satrapies of the Persian empire. Heavily-armoured horsemen proliferated in Persian armies, though the larger part of the cavalry remained lightly equipped; the palton became the main shafted weapon for thrusting and throwing. For combat horsemen formed deep columns and charged to engage the enemy in hand-to-hand fighting. These changes within the Persian cavalry were connected with the long series of wars against the Greeks and an increase in the military character of the Achaemenid landholders' cavalry. The latter was the principal force of satrapal armies, while the mounted militia played an auxiliary part. Darius III's attempt to re-equip his horsemen with long lances in order to compete with the Macedonian Companion cavalry was unsuccessful, as the collapse of Achaemenid power demonstrates. In $324 \mathrm{BC}$, Alexander the Great, as Darius before him, re-equipped noble Persians with xysta suited to hand-to-hand fighting and joined them to the agema of the Companion cavalry (Arr. An. 7.6.5; cf. 8.2; 11.3; Nikonorov 1997: 27), but such horsemen were few in number and Persian horsemen were still fighting with short spears at the end of the 4th century BC.

\section{BIBLIOGRAPHY}

AgAPeEv, A. (1902): Opyt istorii razvitija strategii i taktiki najomnych i postojanych armij novych gosudarstv. (Essay on the History of Development of Strategy and Tactics of Mercenary and Regular Armies of New States). Pt. 1. St. Petersburg.

AleXeEv, A. Ju. (2001): «Kto i kogda byl pogreben v Chertomlykskom kurgane?» Bosporskij fenomen («Why and when was buried in Chertomlyk tumulus?» Bosporan Phenomenon). Pt. 2. St. Petersburg: 137-141.

Alexeev, A. Ju.; Murzin, V. Ju.; Rolle, R. (1994): Chertomlyk (Skifskij tsarskij kurgan IV v. do n. e.) (Chertomlyk (Scythian king's tumulus of the 4th century BC)). Kiev.

Anderson, J. K. (1970): Military Theory and Practice in the Age of Xenophon. Berkeley; Los Angeles.

Andreae, B. (1977): Das Alexandermosaik aus Pompeje. Recklinghausen.

Anisimov, N. V. (1912): Elementarnaja taktika (Elementary Tactics). Pt. 2. St. Petersburg.

BitTnER, S. (1985): Tracht und Bewaffnung des persischen Heeres zur Zeit der Achaimeniden. München.

Breitenbach, H. R. (1967): «Xenophon». Pauly's Real-Encyclopädie der klassischen Altertumwissenschaft. Bd. 2. R. 18: 1707-1742.

CARDASCIA, G. (1951): Les archives des Murašû. Une famille d'hommes des affaires babyloniens à l'époque perse (455-403 av. J.-C.). Paris.

Cook, R. M. (1952): «Dogs in Battle». Festschrift Andreas Rumpf. Zum 60. Geburstag dargebracht von Freuden und Schülern. Im Dezember 1950. Krefeld 1952: 38-42.

Cougny, E. (1877): «Canis». Daremberg Ch., Saglio E. Dictionnaire des antiquités grecques et romaines d'après les textes et les monuments. Paris. T. I. Pt. 1: 877-890.

Dandamayev, M. A.; Lukonin, V.G. (1980): Kul'tura i ekonomika drevnego Irana (Culture and Economy of Ancient Iran). Moscow.

DelBrüCK, H. (1921): Geschichte der Kriegskunst im Rahmen der politischen Geschichte. Tl. 2. Berlin.

Denison, G. T. (1872): «Organizatsia, vooruzhenie i upotreblenie kavalerii na vojne». Vojenaja biblioteka («The Modern Cavalry». Military Library). T. 3. St. Petersburg: 1-194.

DiAKONOFF, I. M. (1956): Istorija Midii ot drevnejshich vremion do kontsa IV v. do n. e. (History of Media from the Origins to the End of the 4th Century BC). Moscow; Leningrad.

17 On the tactics of irregular light cavalry see, for example, the notes of Major Bonneau du Martray in Nolan 1854: 245, n. 1,248, n. 1. 
EBELING, E. (1952): «Die Rüstung eines babylonischen Panzerreiters nach eines Vertrage aus Zeit Darius II.» Zeitschrift für Assyriologie und vorderasiatische Archäologie. N.F. Bd. 16 (Bd. 50): 203213.

Evans, J. A. S. (1984): «Herodotus and Marathon». Florilegium. Vol. 6: 1-27.

Frolov, E. D. (1976): «Ksenofont i ego 'Kiropedija'». Ksenofont. Kiropedija (Xenophon and His Cyropaedia. Xenophon. Cyropaedia. Translated by V.G. Borukhovich and E.D. Frolov). Leningrad: 243-267.

Frolov, E. D. (1991): Fakel Prometeja (Torch of Prometeus). Leningrad.

Golovin, N. N. (1907): Issledovanje boja. Issledovane dejatel'nosti cheloveka kak bojtsa (Research of the Battle. Research of Activity of the Man as a Fighter). St. Petersburg.

GoRELIK, M. V. (1982): «Zashchitnoe vooruzhenie persov i medjan achemenidskogo vremeni» («Defensive Arms of the Persians and Medes in the Achaemenid Time»). Vestnik drevnej istorii. \# 3: 90-106.

Greenhalgh, P. A. L. (1973): Early Greek Warfare: Horsemen and Chariots in the Homeric and Archaic Ages. Cambridge.

Hammond, N. G. L. (1980): «The Battle of the Granicus River». The Journal of Hellenic Studies. Vol. 100: 73-88.

HeAD, D. (1992): The Achaemenid Persian Army. Montvert Publications. Stockport.

Hignett, C. (1963): Xerxes' Invasion of Greece. Oxford.

JäNS, M. (1885): Heeresverfassungen und Völkerleben. Eine Umschau. Allgemeiner Verein für Deutsche Literatur. Berlin.

JoAnNÈs, F. (1981): Textes économiques de la Babylonie récente. Paris.

KeEgan, J. (1986): The Face of Battle. New York.

Khazanov, A. M. (1968): «Cataphractarii i ich rol' v istorii vojenogo iskusstva» (Cataphractarii and His Role in Warfare History). Vestnik drevnej istorii. \# 1: 180-191.

LitTAuer, M. A.; Crouwel, J. H. (1979): Wheeled Vehicles and Ridden Animals in the Ancient Near East. Handbuch der Orientalistik. Abteil. 7. Bd.1. Lief.1. Leiden; Köln.

MCLEOD, W. (1965): «The Rage of Ancient Bow». Phoenix. Vol. 19. \# 1: 1-14.

Marmont, A.-F.-L., de. (1846): De l'esprit des institutions militaires. Bruxelles.

Mertens, J. R. (1987): The Metropolitan Museum of Art: Greece and Rome. New York.

MolevA, N. V. (1998): «Sobaka v religioznych predstavlenijach bosporjan». Bosporskoe tsarstvo kak istoriko-kulturnyj fenomen («Dog in Religion of the Bosporans». Bosporan Kingdom as a Historical-Cultural Phenomenon). St. Petersburg: 60-62.

Munro, J. A. R. (1912): «Dascylium». The Journal of Hellenic Studies. Vol. 32. Pt. 1: 57-67.

Murray, A. S. (1898): Terracotta Sarcophagi Greek and Etruscan in the British Museum. London.

NefEDKIN, A. K. (1997): «Serponosnyje kolesnisty: problema proischozhdenija» (The Scythed Chariots: A Problem of the Origin). Vestnik Sankt-Peterburgskogo universiteta. Series 2. Pt. 2 (\# 9): 22-26.

NEFEDKIN, A. K. (1998): «Stsena boja na zolotoj obkladke nozhen akinaka iz Chertomlyka i voenaja reforma Darija III: k voprosu ob interpretatsii izobrazhenija». Bosporskoje tsarstvo kak istorikokulturnyj fenomen ( «Battle-Scene of Gold Scabbard Akinakes Sheath from Chertomlyk and Darius III' Military Reform: On the Problem of the Representation Interpreter». Bosporan Kingdom as a Historical-Cultural Phenomenon). St. Petersburg: 71-76.

NefEDKIn, A. K. (2001). Chariotry of the Ancient Greeks (16 $6^{\text {th }}-1^{\text {st }}$ centuries B.C.). St. Petersburg (in Russian with English title, contents, and summary).

Nikonorov, V. P. (1997): The Armies of Bactria 700 BC-450 AD. Montvert Publications. Vol. 1-2. Stockport.

NikUlinA, N. M. (1994): Iskusstvo Ionii i Achemenidskogo Irana (Art of Ionia and Achaemenid Iran). Moscow.

Nefiodkin, A. K. (2004): «On the Origin of the Scythed Chariots» Historia. Bd. 53. Hf. 3: 369-378.

Nolan, L.-E. (1854): Histoire et tactique de la cavalerie. Traduit de l'Anglais, avec notes par Bonneau du Martray. Paris.

OrTh, F. (1913): «Hund». Pauly’s Real-Encyclopädie der klassischen Altertumwissenschaft. Bd. VIII. Hbbd. 16: 2540-2582.

PotTiER, E. (1892): «Les sarcophages de Clazomène et les hydries de Caeré». Bulletin de correspondance hellènique. An. 16: 240-262. 
Rahe, A. P. (1980): «The Military Situation in Western Asia on the Eve of Cunaxa». The American Journal of Philology. Vol. 101. \# 1: 79-96.

Richter, G. M. A. (1931): «A Greek Sword Sheath of a Scythian King». Bulletin of the Metropolitan Museum of Art. Vol. 26. \# 1: 44-48.

SeKundA, N. V. (1992): The Persian Army 560-330 BC. Elite Series 42. London.

SeKunda, N. V. (1994): «Classical Warfare». The Cambridge Ancient History. Plates to Vol. V-VI: $167-$ 194.

SHILOV, V. P. (1961): «Raskopki Elizavetinskogo mogil’nika v 1959 g.» (Les fouilles du sépulcre Elisavetovskaïa en 1959). Sovetskaja archeologija. 1961. \# 1: 150-168.

STÄHLER, K. (1992). Griechische Geschichtsbilder klassischer Zeit. EIKON. Bd. 1. Münster.

STOLPER, M. W. (1985): Entrepreneurs and Empire. Leiden.

Tolstou, I.; Kondakov, N. (1889): Russkie drevnosti v pamjatnikach iskusstva (Russian Antiquities of Art Monuments). T. II. St. Petersburg.

WARNERY, Ch.-E., de. (1771): Remarques sur la cavalerie. Lublin.

WiNTER, F. (1912): Der Alexandersarkophag aus Sidon. Strassburg.

Recibido: $18 / 10 / 2005$

Aceptado: 19/10/2006 